\title{
INTRODUCTION TO THE 1987 EDITION
}

\section{Reflections on the First Nuclear War}

"The facts of history are ... not about the motives, real or imaginary, from which individuals suppose themselves to have acted. They are facts about the relations of individuals to one another in society and about the social forces which produce from the actions of individuals results often at variance with, and sometimes opposite to, the results which they themselves intended."

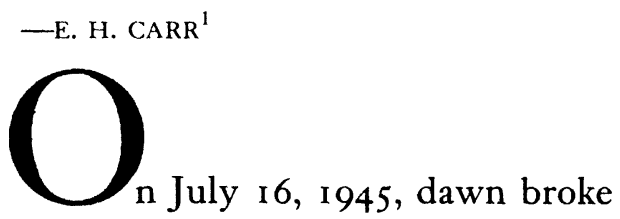

twice over the Alamagordo desert in New Mexico. At 5:30 A.M., thirty minutes before the sun rose, science preempted nature with "a lighting effect ... equal to several suns at midday." Just five and a half years after the discovery of nuclear fission, Manhattan Project scientists had constructed and successfully tested an atomic bomb. By raising the consequences of war to the level of Armageddon, the atomic bomb elevated the stakes of peace beyond historical experience. In physicist I. I. Rabi's cryptic phrase: "Suddenly the day of judgment was the next day and has been ever since."3

From the earliest days of the Manhattan Project, that apocalyptic vision has shaped the debate over nuclear weapons. On one side of the argument are those who insist that the dangers inherent in large nuclear arsenals overwhelm any need for their existence. Focusing on the consequences of a nuclear war, those who argue this case have sought to minimize the number of nuclear weapons and deemphasize their military and diplomatic roles.

On the other side of the debate are those who view the dangers inherent in nuclear weapons as both a guarantor of U.S. national security and as an effective instrument of diplomatic and military power. Impressed by the logic of nu- 


\section{xxii \\ Introduction}

clear deterrence, adherents of this point of view have sought to maximize both the quality and quantity of nuclear weapons in the U.S. arsenal and to promote their military and diplomatic utility.

The assumptions and attitudes that support these opposing views were formulated in secrecy during World War II. At its beginning they were implicit in the discussions that led to the decision to build atomic bombs. Near the end of the war they were made explicit in the discussions that led to their use against urban targets. The fiery atomic spectacles that marked the war's conclusion marked, too, the debate's first and most important resolution.

Indeed, many of the most powerful forces that have shaped the postwar world were unleashed by the mushroom clouds that rose over Japan in August 1945: the beginning of the nuclear arms race and the possible extinction of the human race; the moral sway of American power and the ability of technology to overwhelm morality; the conflicting ambitions of the wartime allies and the mutual interests of former enemies. For these reasons, Hiroshima marked a beginning not an end, though it remains a point of sharp contention as to whether its destruction ended the possibility of a more hopeful start to the nuclear age.

The circumstances and considerations that led to the atomic bombings of Hiroshima and Nagasaki are addressed throughout $A$ World Destroyed. But since its original publication, I have become increasingly interested in the relationship between the wartime history of the atomic bomb and the postwar nuclear arms race--between the assumptions and attitudes that justified urban bombing as a strategy for winning the war, and the arguments and expectations that have rationalized nuclear deterrence as an instrument of American policy ever since. These considerations have prompted me to revise the subtitle for this new edition (the original subtitle was "The Atomic Bomb and the Grand Alliance") and to explore in this new Introduction some of the legacies of what we must learn to recognize as the first nuclear war. 
In 1983 I. I. Rabi spoke at the Los Alamos Scientific Laboratory during the fortieth-anniversary reunion marking the founding of the facility, where the bombs dropped on Hiroshima and Nagasaki were designed and assembled. "History is a very important thing," he said, "because by perusal of history you see the greatness and the folly of humanity." The history of the Manhattan Project was his case in point. The scientists who constructed those weapons at Los Alamos had been drawn to the task in order "to save Western civilization" from fascism, by building an atomic bomb before the Germans. Then, on the eve of success, they undertook to save civilization from the atomic bomb itself, by devising formulas to prevent a nuclear arms race.* But, to borrow the historian E. H. Carr's words, the outcome was "opposite to the results which they themselves intended."

Most students of this subject are aware of the numerous ironies associated with the rescue efforts launched by the atomic scientists at the end of the war and during its immediate aftermath. But one ironic twist that has gone almost unnoticed is particularly poignant: virtually all of the basic ideas associated with nuclear weapons today-many of them ideas that have contributed to nuclear escalation and proliferation-derive from attitudes, assumptions, and expectations formulated during the war for the purpose of preventing a nuclear arms race afterward.

The nuclear "bargaining chip" for arms control negotiations, a concept first suggested by James B. Conant in 1944, was adopted in 1946 by Bernard Baruch, who presented the U.S. plan for the international control of atomic energy to the United Nations. Nuclear intimidation, the psychological premise of nuclear containment, was anticipated in 1945 at the atomic bomb targeting committee meetings in Los

* See Appendices R, S, and T. These documents have been added to this edition to underscore the continuity between the decisions to use the atomic bomb and the moral, political, and strategic dilemmas posed by the nuclear arms race. 
Alamos. Limited nuclear war, an idea first popularized in $195^{8}$ by Henry Kissinger's Nuclear Weapons and Foreign Policy and then adopted in 1980 as Presidential Directive-59 by the Carter Administration, was discussed during the war as an integral part of the effort to bring the Soviet Union to accept the international control of atomic energy. A strategic defense against nuclear weapons was first raised in 1942 by Arthur Compton, who urged a crash program for researching and developing "counter measures" against a German atomic bomb. Deterrence, and even the "warning shot" strategy, were concepts implicit in the decisions that led to the destruction of Hiroshima and Nagasaki.

The more we reflect upon these historical origins, the more disquieting are the reverberations of the title Rabi chose for his speech: "How Well We Meant."

\section{Hiroshima as Moral History}

More than four decades after the destruction of Hiroshima and Nagasaki, the relevance of the fate of those cities has not diminished, nor have the debates they ignited. No one who looks closely at those debates will fail to recognize that there are issues at stake that go beyond military history. There are questions of morality, national character, and this nation's responsibility for the shape of the postwar world. Hiroshima not only introduced the nuclear age, it also served as the symbolic coronation of U.S. global power. The atomic bomb, as more than one contemporary cartoonist depicted it, was our scepter, and its use contributed to the image of our international authority.

But military power was not the only foundation for authority. "The position of the United States as a great humanitarian nation" was also important, Under Secretary of the Navy Ralph Bard wrote to the Secretary of War on June 27, 1945.* Urging that the Japanese be warned several days prior to the attack, Bard sought to modify the decision taken

* See Appendix O. 


\section{$\mathrm{xxV}$ \\ Introduction}

on May 3 I that "we could not give the Japanese any warning; that we could not concentrate on a civilian area; but that we should seek to make a profound psychological impression on as many of the inhabitants as possible." "At the suggestion of Dr. [James B.] Conant the Secretary [of War Henry L. Stimson) agreed," the minutes of the Interim Committee continued: "the most desirable target would be a vital war plant employing a large number of workers and closely surrounded by workers' houses" (emphasis added).*

Bard's advice went unheeded, however, and an early irony of Hiroshima was that the very act symbolizing our wartime victory was quickly turned against our peacetime purposes. At the 1946-1948 Tokyo War Crimes Trials, which, like the Nuremberg trials, were a symbolic expression of our moral authority, Justice Radhabinod Pal of India cited Hiroshima and Nagasaki as evidence against our claim to rule by right of superior virtue. The atomic bombings, he wrote in a dissenting opinion, were "the only near approach [in the $\mathrm{Pa}$ cific War] to the directive ... of the Nazi leaders during the Second World War."

President Truman's earliest public explanations for the bombings of Hiroshima and Nagasaki addressed the issues of just cause and morality that Pal later raised. "We have used [the atomic bomb]," he stated, "in order to shorten the agony of war, in order to save the lives of thousands and thousands of young Americans." But several days later he added less lofty reasons. Responding to a telegram criticizing the atomic bombings, the President wrote:

Nobody is more disturbed over the use of Atomic bombs than I am but I was greatly disturbed over the unwarranted attack by the Japanese on Pearl Harbor and their murder of our prisoners of war. The only language they seem to understand is the one we have been using to bombard them.

When you have to deal with a beast you have to treat

* See Appendix L. 
him as a beast. It is most regrettable but nevertheless true. ${ }^{7}$

But in the aftermath of Hiroshima, many thoughtful commentators began to view the bomb itself as the "beast." "For all we know," H. V. Kaltenborn, the dean of radio news commentators, observed on August 7, "we have created a Frankenstein! We must assume that with the passage of only a little time, an improved form of the new weapon we use today can be turned against us." 8

At some level, this thought has been the enduring nightmare of the nuclear age, a vision of an inevitable holocaust imbedded deep within our culture. "How does the universe end?" Billy Pilgrim, the protagonist in Kurt Vonnegut's Slaughterhouse Five, asks his omniscient Trafalmadorian captors. The novel continues:

"We blow it up, experimenting with new fuels for our flying saucers. A Trafalmadorian test pilot presses a starter button, and the whole Universe disappears."

"If you know this," said Billy, "isn't there some way you can prevent it? Can't you keep the pilot from pressing the button?"

"He has always pressed it, and he always will. We always let him and we always will let him. The moment is structured that way." 9

The structure of the nuclear age-deterrence and the inexorable accumulation of the weapons designed to promote its purposes-has encouraged a deadening sense that there are forces at work beyond political control. The American public's feeling of powerlessness before those forces may be the single most important reason behind the belief that a massive arsenal of nuclear weapons is needed to guarantee our national security. Even here, the moral dimension of the debate over the atomic bombings of Hiroshima and Nagasaki is relevant, for it is of paramount importance to those who wish to rely upon nuclear weapons that they are not 


\section{xxvii \\ Introduction}

tarnished with a sense of guilt that could inhibit their use as an instrument of diplomacy.

This concern about the practical effects of "Hiroshima guilt" was discussed soon after the war by the Manhattan Project's chief science administrator, James Conant, who had returned full time to his post as president of Harvard University. Raising the issue in a letter to former Secretary of War Henry L. Stimson, he wrote of his concern about the "spreading accusation that it was entirely unnecessary to use the atomic bomb at all," particularly among those he described as "verbal minded citizens not so generally influential as they were influential among the coming generations of whom they might be teachers or educators." To combat that view, he urged Stimson to write an article on "the decision to use the bomb," which subsequently appeared in the February 1947 issue of Harper's magazine. ${ }^{10}$

If "the propaganda against the use of the atomic bomb had been allowed to grow unchecked," Conant wrote to Stimson after reading a prepublication version of the article, "the strength of our military position by virtue of having the bomb would have been correspondingly weakened," and the chances for international control undermined. "Humanitarian considerations" that led citizens to oppose the strengthening of the U.S. atomic arsenal, in Conant's opinion, were likely to subvert the common effort to achieve an international atomic energy agreement. "I am firmly convinced," he told Stimson, "that the Russians will eventually agree to the American proposals for the establishment of an atomic energy authority of world-wide scope, provided they are convinced that we would have the bomb in quantity and would use it without besitation in another war." 11

Stimson's article responded to Conant's practical concerns. Explaining the steps in the decision strictly in the context of the Pacific War and the objective of "avoiding the enormous losses of human life which otherwise confronted us," he left no room for the suggestion that considerations beyond the war could have been factors, or that in future similar circumstances the government would not be com- 
pelled to take similar actions. The war had not ended when the bomb became available; the decision flowed inexorably out of those circumstances: "In light of the alternatives which, on a fair estimate, were open to us I believe that no man, in our position and subject to our responsibilities," Stimson wrote, "holding in his hands a weapon of such possibilities, could have failed to use it and afterwards looked his countrymen in the face." 12

The primary argument for the "necessity" of using the atomic bomb was saving American lives. President Truman wrote in his memoirs that half a million U.S. soldiers would have been killed had the planned invasions been launched. Winston Churchill claimed that the figure was closer to a million. ${ }^{13}$ Could any responsible Commander-in-Chief send so many young men to die on foreign shores when an alternative like the atomic bomb was readily at hand?

As stated, the question answers itself. As stated, it also distorts the nature of the historical problem. Before the decision to use atomic bombs can be properly understood, many other questions need to be considered. They range from the expected impact of the use of the bomb on the Japanese during the war to the influence such a demonstration might have on the Soviet behavior afterward. They include questions related to bureaucratic momentum and political expediency; to the instinct for revenge as well as the pressure for results; to scientific pride and economic investments; to Roosevelt's legacy and Truman's insecurity.

In the original edition of $A$ World Destroyed I sought to analyze these questions within their historical context, limiting the discussion to what was said and done before the bombs were dropped. My narrative tacitly accepted the published casualty estimates as a compelling influence limiting decision makers' choices. But recently discovered estimates of invasion casualties dramatically contradict the figures released by Truman, Churchill, and Stimson. These require some comments on the information that has shaped the postwar debate.

Historians have known for decades that several alterna- 


\section{xxix \\ Introduction}

tives to atomic bombing or an invasion of Japan were considered during May and June $1945 .{ }^{14}$ The first was to modify unconditional surrender. Having broken the Japanese diplomatic code, the Department of State's Far Eastern specialists were sanguine that the peace advocates in the Imperial Cabinet could win capitulation if the United States assured Japan that it would maintain the Emperor and the Imperial Dynasty. The second alternative was to delay the atomic bombings until after August 8, the final day on which Stalin could live up to his agreement to enter the war against Japan within three months after Germany's surrender.* The third alternative, Admiral William D. Leahy wrote to the Joint Chiefs of Staff on June 14, 1945, was "to defeat Japan by isolation, blockade, and bombardment by sea and air forces." $\dagger$

All of these suggestions were viable alternatives, but none of them was without its particular disadvantages.

The first option, modifying unconditional surrender, was politically risky. Introduced by Roosevelt and accepted by the Allies, the unconditional surrender had become the basis upon which the public expected the war to be concluded. From the point of view of Truman and his advisers, tampering with this doctrine appeared fraught with unattractive political dangers.市

Second, a Japanese surrender (precipitous or otherwise) following the entry of the Soviet Union into the Pacific War would have facilitated the expansion of Soviet power in the Far East. By the summer of 1945 such an option was anathema to Truman and his advisers.

Finally, continuing the blockade and bombardment promised no immediate results and might, as the Joint War Plans Committee wrote to the President, "have an adverse effect upon the U.S. position vis-à-vis other nations who will, in

* On August 8 the Soviet Union declared war on Japan.

† See Appendix U.

$\ddagger$ Nevertheless, after the Soviets declared war on Japan and after both available bombs had been dropped, unconditional surrender was modified according to the terms stated above. 


\section{$\mathrm{xxx}$ \\ Introduction}

the meantime, be rebuilding their peacetime economy."*

In the summer of 1945 it was therefore not the lack of an alternative that might induce Japan's surrender that led to the use of atomic bombs. It was the undesirability of relying on the available alternatives given the nuclear option. The nuclear option was preferred because it promised dividends-not just the possibility that it would end the war but the hope that it would eliminate the need to rely on one of the other alternatives.

The question of how policymakers came to understand their choices is probed throughout $A$ World Destroyed. It is a question we should keep before us as the recent discovery of the actual invasion casualty estimates should make clear. The casualty estimates announced by Truman in the aftermath of Hiroshima were grossly exaggerated, as documents reproduced in Appendix $U$ demonstrate. For example, on June 1 5, 1945, the Joint War Plans Committee (JWPC) estimated that about 40,00o Americans would be killed and I 5o,ooo wounded if both southern Kyushu and the Tokyo plain had to be invaded (on November 1, 1945, and March I, 1946, respectively). ${ }^{15}$ General George C. Marshall, Army Chief of Staff, who Truman cited in his memoirs as the source of the estimate that an invasion would cost "half a million American lives," endorsed an estimate on June 7 that was similar to the one produced a week later by the Joint War Plans Committee. ${ }^{16}$ On June I 8, General Douglas MacArthur, the commander of U.S. Pacific forces, concurred with the range of JWPC's estimates. ${ }^{17}$ On July 9 a memorandum to the Joint Staff Planners entitled "Note by the Secretaries" included a revised casualty estimate of $3 \mathrm{I}$, ooo killed, wounded, and missing for the first 30 days of the planned operation against Kyushu. $†$

In the end the most destructive conventional war of the

* See Appendix U.

+ See Appendix U. During the first 30 days of the Normandy invasion, the killed/wounded/missing count for U.S. troops was 42 ,ooo. 


\section{xxxi \\ Introduction}

century was concluded with the first nuclear warfare in history. Many who advocated that alternative hoped it would contribute to a postwar settlement that would banish those weapons - others hoped it would establish their value. But whatever they believed, those who felt called upon to defend the bombing of Hiroshima and Nagasaki came to recognize more clearly in retrospect what a few had warned in prospect: that nuclear war was beyond the reach of conventional moral categories.

Though no American President could be expected to have chosen an invasion of Japan if a plausible alternative was available, the fact that several available alternatives had been rejected increased the moral burden of justifying the extraordinary consequences of Hiroshima and Nagasaki. Americans had self-consciously fought World War II to preserve the values of their civilization. Is it surprising that in its aftermath those who had directed the war conspired to explain its terrible conclusion as unavoidable and consistent with those values?

Reflecting on the choices the administration had faced in the summer of 1945 , former Secretary of War Stimson felt compelled to admit the possibility that refusing to modify unconditional surrender might have been a mistake - a mistake that could have delayed the end of the war. Composing his memoirs several years after the war, he wrote "that history might find that the United States, by its delay in stating its position [on the conditions of surrender], had prolonged the war." 18

Despite Stimson's singular remark, and the general availability of information about the other options, the invasion has remained the alternative to the atomic bombings in public discussions. Perhaps this is because the invasion remains the least ambiguous of the options. Or perhaps it is because it lends to the bombings an implicit moral legitimacy. According to the figures released, the magnitude of the projected slaughter of invading Americans was even greater than the actual slaughter of Japanese civilians. As reports, 


\section{xxxii \\ Introduction}

images, and tales of death, dying, and suffering from nuclear warfare filtered into the American press, the alternatives to the invasion were filtered out. ${ }^{19}$

The manipulation of the estimated casualty figures, and thereby the history of the decision-making process that led to the atomic bombings of Hiroshima and Nagasaki, has masked an important lesson. The choice in the summer of I 945 was not between a conventional invasion or a nuclear war. It was a choice between various forms of diplomacy and warfare. While the decision that Truman made is understandable, it was not inevitable. It was even avoidable. In the end, that is the most important legacy of Hiroshima for the nuclear age.

\section{Los Alamos and Hiroshima}

The confluence of the invention of weapons that could destroy the world and a foreign policy of global proportions removed the physical and psychological barriers that had protected the United States from the full force of international affairs before World War II. In the context of the cold war, politics no longer stopped at the water's edge. On the contrary, politics often began there. No group of Americans was more alert to this change than the scientists of the Manhattan Project, who had brought it about. To Robert Oppenheimer, the new alignment of science and power threatened "the life of science [and] the life of the world." The change in scale and stakes involved scientists more, he said, "than any other group in the world." The existence of the atomic bomb linked science to national security and made scientists into military assets. The twin "evils of secrecy and control strike at the very roots of what science is and what it is for," Oppenheimer warned his former colleagues at Los Alamos in November $1945 .^{20}$

The question of the meaning and uses of science raised by Oppenheimer took on a new sense of immediacy for all scientists after the war. With the advent of the atomic age, the 
answer to the question of science and the state inevitably became tied to the political and national defense issues generated by the cold war. As a result, the boundary between science and politics blurred, and the public's attitude toward science was increasingly defined by political criteria. In such an environment Bernard Baruch could suggest that "science should be free but only when the world has been freed from the menaces which hang over us." 21

The scientists disagreed. Fearing that science would become the first political victim of their success, Percy W. Bridgman, the president of the American Physical Society, responded to the threat of external control of science with the declaration that "society is the servant of science.... Any control which society exerts over science and invention must be subject to this condition."22

With Bridgman, the scientist's, view at one pole and the converse approach expressed by Baruch at the other, it is not too much to suggest that there arose a split between "two cultures." But it was not, as C. P. Snow argued, a division having to do with a nonscientist's knowledge of the second law of thermodynamics or a scientist's ability to quote Shakespeare. It touched upon a deeper issue-the nature of freedom and power in a democratic society.

Oppenheimer spoke of this issue from a scientific perspective in answering the question he had raised. "If you are a scientist," he said, "you believe that it is good to find out how the world works ... that it is good to turn over to mankind at large the greatest possible power to control the world and to deal with it according to its lights and its values." It was not for the scientist to judge, he implied, whether those lights and values were adequate to control new understandings. Nor was it for society to judge, he added explicitly, what the scientist should and should not seek to discover. Any such external control "is based on a philosophy incompatible with that by which we live, and have learned to live in the past." ${ }^{23}$ If society was not the servant of science, it certainly was a collaborator. To politicize science was to destroy it. A free state could only be well served by science if 
scientists were free to publish and discuss their research. A state was not free, he implied, if the life of science was not open and free of political control.

To keep politics out of science, scientists responded politically. Some counseled the Administration privately against policies that would lead to military control, while others led a successful campaign against military domination of the Atomic Energy Commission. However, in the ensuing cold war, civilian control of atomic energy proved to be illusory. Military requirements held sway, loyalty and security programs were vigorously enforced, and government support led to far more control than anticipated. Though scientists gained greater opportunities to participate in policy formulation, their advice was expected to support basic policies decided by others. This was the clear message communicated by the removal of Oppenheimer's security clearance in I954. $^{24}$

After the war, the scientific community itself appeared to divide "culturally." Scientists such as Oppenheimer, Vannevar Bush, James Conant, Ernest Lawrence, and Karl and Arthur Compton worked closely with the government. In contrast, Leo Szilard, Eugene Rabinowitch, and other leaders of the Federation of American (Atomic) Scientists became vocal critics of the Truman Administration's policies. The division among scientists was fundamentally political, yet both groups shared an abiding faith in science. The scientific community was united by an unstated assumption that what was good for science was good for world peace. But how was peace best attained?

All scientists agreed that avoiding an atomic arms race with the Soviet Union was the most important issue of the day. The revolution in weapons technology, they maintained, could lead either to a peaceful diplomatic revolution or a nuclear-armed world. If an arms-control plan was not adopted, an arms race would harness science to military requirements. To avoid this catastrophe the veterans of the Manhattan Project lobbied vigorously to scuttle the military's attempt to capture the atom. 
The outlines of that debate emerged during the war and became established soon afterward. Though only i 3 atomic bombs existed in 1947 , by 1948 the number had escalated to $50 .{ }^{25}$ In 1949, when the Soviet Union exploded its first atomic bomb, President Truman faced conflicting recommendations. One group of scientists and politicians urged him to opt for a program to develop a hydrogen bomb, a proposal that represented a "quantum leap" into the realm of megaton weapons. On the other side of the argument were the scientists of the Atomic Energy commission's General Advisory Committee (GAC), who recommended against such an escalation, proposing instead that the President adhere to the principle of sufficiency. "To the argument that the Russians may succeed in developing [the hydrogen bomb]," the members of GAC wrote in October 1949 to the President, "we would reply that our undertaking it will not prove a deterrent to them. Should they use the weapon against us, reprisals by our large stock of atomic bombs would be comparably effective to the use of a super [H-bomb]." The moral consequences of technology were also at issue. "We base our recommendation," the committee members also wrote, "on our belief that the extreme dangers to mankind inherent in the proposal [for a super] wholly outweigh any military advantage that could come from this development."26

But in January $195^{\circ}$ Truman opted for the hydrogen bomb. The principle of the nuclear containment of the Soviet Union-an idea that was first developed during the war in the context of the decision to use the atomic bomb against Japan-was now firmly set in place.

On October 16, 1945, his last day as director of the Los Alamos Scientific Laboratory, Robert Oppenheimer, who would write the GAC's report opposing the "super," accepted a certificate of appreciation from the Secretary of War on behalf of the laboratory with these words:

It is our hope that in years to come we may look at this scroll, and all that it signifies, with pride. 
Today that pride must be tempered with a profound concern. If atomic bombs are to be added as new weapons to the arsenals of a warring world, or to the arsenals of nations preparing for war, then the time will come when mankind will curse the names of Los Alamos and Hiroshima. $^{27}$

In the context of a nuclear-armed world, "how well they meant" and "how well we mean" cannot be the central points. 